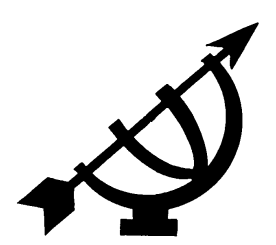

\title{
Abraham Kuyper en die reg op selfbeskikking van bevolkingsgroepe
}

\author{
Johan D. van der Vyver \\ I.T. Cohen Professor of International Law and Human Rights \\ Emory University School of Law \\ Gambrell Hall \\ ATLANTA, GA 30322 \\ E-pos: jvyver@law.emory.edu
}

\begin{abstract}
Abraham Kuyper and the right to self-determination of peoples
\end{abstract}

Sphere sovereignty as a principle that regulates the mutual relationships among different social institutions originated from the philosophy of John Althusius, and this idea is found again in one form or another in the theories of various German political and legal philosophers. However, the descriptive name of this principle derives from the Dutch politician, Guillaume Groen van Prinsterer, who under the influence of Julius Stahl, confined the principle to church-state relationships. The special contribution of Abraham Kuyper was to extend sphere sovereignty to relationships among other social institutions. However, Kuyper did not distinguish precisely between the kinds of "circles" which in principle qualify for sphere sovereignty, and in the process he also included social communities among those with sphere sovereignty. An accurate distinction among social institutions that do qualify for sphere sovereignty and (unstructured) social communities that do not, derived from the philosophy of the cosmonomic idea of Herman Dooyeweerd. Kuyper's perception of sphere sovereignty of social communities does correspond with the right to self-determination of ethnic, religious and linguistic communities as currently defined in international law. This right, however, does not include the right to secession from an existing state, but affords to the communities concerned the right to promote their culture, to testify to and practise their religion and to speak and apply their language without state interference. 


\section{Opsomming}

\section{Abraham Kuyper en die reg op selfbeskikking van bevolkings- groepe}

Soewereiniteit in eie kring as 'n beginsel wat die onderlinge verhouding tussen verskillende sosiale instellings bepaal, vind sy oorsprong in die wysbegeerte van Johannes Althusius, en dié idee word later weer in die een of ander vorm teruggevind in die denke van verskeie Duitse staats- en regsfilosowe. Die beskrywende naam van hierdie beginsel kom egter van die Nederlandse staatkundige, Guillaume Groen van Prinsterer, wat in navolging van veral Julius Stahl, die beginsel beperk tot kerk-staatverhoudings. Abraham Kuyper se besondere bydrae was om soewereiniteit in eie kring ook op die verhoudings tussen ander sosiale instellings van toepassing te maak. Kuyper het egter nie noukeurig onderskei tussen die soorte "kringe" wat in beginsel vir soewereiniteit in eie kring kwalifiseer nie en het daarby ook sosiale gemeenskappe ingesluit. 'n Noukeurige onderskeid tussen sosiale instellings (verbande) wat wel op soewereiniteit in eie kring aanspraak kan maak, en (ongestruktureerde) sosiale gemeenskappe wat nie daarvoor kwalifiseer nie, spruit uit die Wysbegeerte van die Wetsidee van Herman Dooyeweerd. Kuyper se siening van sosiale gemeenskappe se soewereiniteit in eie kring stem egter ooreen met etniese, godsdienstige en taalgroepe se reg op selfbeskikking soos wat dit tans in die volkereg gedefinieer word. Hierdie reg sluit nie die reg op sesessie van 'n bestaande staat in nie, maar verleen aan die betrokke gemeenskappe die reg om sonder staatsinmenging hulle eie kultuur te bevorder, hulle eie godsdiens te bely en te beoefen, en hulle eie taal te praat en te gebruik.

\section{Inleidend}

In 1898 het Abraham Kuyper (1837-1920) 'n reeks lesings oor die Calvinisme, bekend as die Stone-lesings, by Princeton Universiteit in die VSA gelewer. In hierdie lesings getuig Kuyper van sy besondere hoogagting vir die Amerikaanse grondwetlike waarborge van "vrijheid van eeredienst en juxtapositie van kerk en staat" (Kuyper, 1898:87). Hy moes egter ook wal gooi. Volgens tradisionele Calvinistiese leerstellinge was dit vir die staat beskore om godsdienstige waarhede van valshede te onderskei en veroorloof om die verkondigers van allerlei vorme van kettery te straf. Wat hierdie praktyk betref, kan die volgende vraag egter gevra word: Was hierdie praktyk dan nie juis in beginsel die basis vir die 
vervolging van die gelowiges gedurende die vroeë Christendom en van Protestante tydens die Reformasie nie?

\section{Calvyn oor reg en godsdiens}

Die regsleer van Johannes Calvyn (1509-1564) was verteenwoordigend van 'n sintese tussen die natuurregsleer van die Grieke en bepaalde Ou-Testamentiese aanwysings (vgl. Calvyn, 1568:4. 20.16; Afrikaanse vertaling - JDvdV):

Terwyl dit nou vasstaan dat die wet van God, wat ons die morele wet noem, niks anders is nie as 'n verklaring van natuurreg en van daardie gewete wat deur God in die menslike verstand ingeprent is, is die gehele billikheidsreël waarvan ons nou praat, ook daarin vervat.

Natuurreg beteken vir Calvyn norme van wat die reg behoort te wees, en die inhoud daarvan word volgens hom aan die Mosaïese wette ontleen. Nie alle Mosaïese wette stel egter universele standaarde nie, en daar moet dus onderskei word tussen daardie wette wat wel algemeen geldig is en dié wat slegs vir die kinders van Israel gegeld het in die lig van die besondere plek- en tydsomstandighede van destyds (Calvyn, 1568:4.20.16). In die eersgenoemde kategorie vind ' $n$ mens die instelling van private eiendomsreg en van straf vir onregmatige optrede, terwyl die Mosaïese verbod op rente en borgskap nie die universele geldigheid wat die natuurreg kenmerk, geniet het nie.

In Kommentare op die Dekaloog lei Calvyn juridiese beginsels van die Tien Gebooie af wat na sy mening in elke regsisteem ingesluit behoort te word - dit is, met uitsluiting van die Vierde en die Tiende Gebooie wat respektiewelik te make het met die eerbiediging van die Sabbat en die verbod op sekere menslike begeertes. Volgens Calvyn is die Sabbatsgebod volbring met die koms van Jesus Christus (Calvyn, 1949:61-62); en wat die Tiende Gebod betref, argumenteer Calvyn dat die reg alleen betrekking behoort te hê op uitwendige menslike handelinge en hom nie met innerlike menslike begeertes moet bemoei nie (Calvyn, 1568:2.8.6).

Vir die doeleindes hiervan is dit veral van belang om daarop te let dat die eerste tafel van die Dekaloog, wat te make het met die direkte verhouding tussen God en mens, volgens Calvyn ook natuurregtelike beginsels behels wat deur die staat afgedwing behoort te word. Die staat moet daarom nie alleen ingryp in die geval van opstand teen ouerlike gesag, manslag, onkuisheid, 
diefstal en valse getuienis nie, maar is ook geroepe om die Christelike geloof te bevorder, om 'n verbod te plaas op afgodery, en om godslastering op straf te verbied. Die juridiese toepassing van die Eerste Gebod behels volgens Calvyn 'n plig van die staat om valse godsdienste te verbied. In 'n brief van 9 September 1553, gerig aan Antistes Sulzer van Basel in Switserland, dring Calvyn aan op die doodstraf in 'n geval van kettery (Calvyn, 1553).

Hierdie Calvinistiese leerstellinge vind 'n mens terug in Artikel 36 van die Nederlandse Geloofsbelydenis:

Ons glo dat God vanweë die verdorwenheid van die menslike geslag konings, vorste en owerhede aangestel het. Dit is immers sy wil dat die wêreld deur middel van wette en regerings geregeer moet word, sodat die losbandigheid van die mense in bedwang gehou kan word en alles onder die mense ordelik kan verloop. Vir dié doel het Hy die owerheid die swaard in die hand gegee om die kwaaddoeners te straf (Rom. 13:4) en die deugsames te beskerm. En dit is nie alleen hulle taak om aan die staatsbestuur aandag te gee en daaroor te waak nie maar ook om die heilige Woordopenbaring te beskerm, om sodoende alle afgodery en valse godsdiens teen te gaan en uit te roei, die ryk van die antichris te vernietig en die koninkryk van Jesus Christus te bevorder, die Woord van die evangelie orals te laat verkondig, sodat God deur elkeen geëer en gedien word soos Hy in sy Woord beveel.

In die Stone-lesings beklemtoon Kuyper die praktyk van vrye godsdiensbeoefening in Calvinistiese lande; en hierdie empiriese tradisie, eerder as die teoretiese voorveronderstellings wat in Calvyn se Kommentare opmerklik is, verteenwoordig die ware gees van die Calvinisme. Daardie empiriese tradisie word weerspieël in 'n leerstuk wat die soewereiniteit van sosiale instellings, insluitende kerk en staat, elk binne 'n eie interne sfeer van funksies, voorop stel.

\section{Soewereiniteit in eie kring}

\subsection{Historiese perspektief}

Die term "souvereiniteit in eigen sfeer" is in 1862 vir die eerste keer deur Guillaume Groen van Prinsterer (1801-1976) gebruik om die verhouding tussen kerk en staat aan te dui (Groen van Prinsterer, 1862:30-31). Die idee self het egter hierdie beskrywende frase met ongeveer 300 jaar voorafgegaan. Volgens Herman Dooyeweerd tref 'n mens die eerste "moderne" formulering van die beginsel van soewereiniteit in eie kring in sosiale verhoudings by die Middeleeuse 
Calvinistiese denker, Johannes Althusius (1557-1638), aan (Dooyeweerd, 1984:663; vgl. ook Dooyeweerd, 1950:7-8). Althusius verklaar naamlik dat verskillende sosiale entiteite almal onderworpe is aan hulle eie wette, en dat daardie wette in elke geval van mekaar verskil ooreenkomstig die tipiese aard van die betrokke sosiale instelling (Althusius, 1614:1.19). ${ }^{1}$

In die 300 jaar wat Althusius en Groen van Prinsterer van mekaar skei, het die konsep van sosiale instellings se interne soewereiniteit van tyd tot tyd kop uitgesteek, meestal in die geledere van Lutherse staatkundiges en hoofsaaklik beperk tot kerk-staatverhoudings. Georg Friedrich Puchta (1798-1846) praat byvoorbeeld van die "Selbstständigkeit" van die kerk as "'n instelling naas die staat" (Puchta, 1865:1.1.14), en van die kerk wat homself onderskei "op grond van die andersoortigheid van sy wese" (Puchta, 1865:1.2.25). ${ }^{2}$ Hoewel hierdie uitspraak dui op soewereiniteit in eie kring in kerk-staatverhoudings (Dengerink, 1948:60), het Puchta nie daartoe gekom om die beginsel ook op ander sosiale entiteite van toepassing te maak nie.

Georg Beseler (1809-1888) het weer op sy beurt aangedring op die "soewereine" wetgewende magte van plaaslike besture (Beseler, 1885:1.1.17), welke soewereiniteit hy dan omskryf as "die bevoegdheid wat aan sekere korporasies toebehoort om na eie oordeel hulle eie wette (diskresionêre voorskrifte, statute, opsionele dekrete) neer te lê binne die gebiede wat deur hulle beheer word en in elk geval met betrekking tot hulle eie aangeleenthede" (Beseler, 1885:1.2.1.1.B26). ${ }^{3}$ Beseler voer aan dat plaaslike en streeksowerhede nie hulle ius particulare aan die sentrale wetgewer of aan gewoonte ontleen nie, maar dat daardie besondere reg voortspruit uit die "tot regsoortuiging bevoegde wil (die outonomie) van ' $n$ korporasie, wat sigself soortgelyk as wetgewing in ' $n$

1 Propriae leges sunt cujusque consociationis peculiares, quibus illa regitur. Atque hae in singulis speciebus consociationis aliae atque diversae sunt, prout natura cujusque postulat (Althusius, 1614:1.19).

2 “... durch die Ungleichartigkeit ihres Wesens” (Puchta, 1865:1.2.25).

3 “... die gewissen Corporationen zustehende Befugnis, sich innerhalb des von innen beherrschten Kreises oder doch für ihre besonderen Angelegenheiten nach freiem Ermessen ihr eigenes Recht (Willküren, Statute, Beliebungen) zu setzen" (Beseler, 1885:1.2.1.1.B26). 
bepaalde regsvormende handeling openbaar" (Beseler, 1885 1.1.17). 4

Friedrich Julius Stahl (1802-1861) - die persoon wat 'n besondere invloed op Groen van Prinsterer gehad het - het weer soewereine magte in die streng sin van die woord alleen tot kerk en staat beperk. Stahl voer aan dat hierdie twee instellings onafhanklike plekke in die samelewing naas mekaar beklee (Stahl, 1853:16, 18), dat die kerk "' $n$ instelling van 'n algehele verskillende aard" is (Stahl, $1862: 72),{ }^{5}$ en dat "kerklike bewind ... streng van wêreldlike bewind onderskeibaar is" (Stahl, 1862:13;6 vgl. ook Stahl, 1862:8, 47, 184).

Groen van Prinsterer het soewereiniteit in eie kring ook tot kerkstaatverhoudings beperk. Hy het dikwels gepraat van "de zelfstandigheid van den staat tegenover de kerk ten gevolge van eigen onmiddellijke onderwerping aan God" (Groen van Prinsterer, 1846/1847:130 vn. 21, ingevoeg by die oorspronklike teks in 1868). Hy definieer die kerk as 'n geloofsgemeenskap met sy eie karaktertrekke, waarvan 'n belydenis 'n essensiële element is (Groen van Prinsterer, 1849:45, 68; vgl. ook Groen van Prinsterer, 1862:15, waar hy van die "eigenaardige werkkring" van die kerk praat). In een van sy vroeëre werke verklaar hy: "De staat is niet aan de kerk, maar, met de kerk, aan de geboden Gods ondergeschikt" (Groen van Prinsterer, 1872:679). Hy voeg daaraan toe dat die staat 'n mate van beheer oor die kerk moet uitoefen. Dit is eers nadat hy later die "mate-van-beheer"-idee prysgegee het dat die konsep van soewereiniteit in eie kring by hom tot volle wasdom gegroei het. Hy vat dit soos volg saam: "Onderwerping van overheden en onderdanen, niet aan de geestelijkheid, maar aan de goddelijke wet, is de beste waarborg tegen verdrukking" (Groen van Prinsterer, 1858:91; vgl. ook 1855:14).

4 “... in dem zur Rechtserzeugung befugten Willen (der Autonomie) einer Corporation, welche sich ähnlich, wie die Gesetzgebung es thut, in einem bestimmten, die Rechtsregel constituierenden Act offenbar" (Beseler, 1885:1.1.17).

$5 \quad$ “... eine Institution ganz anderer Art” (Stahl, 1862:72).

$6 \quad$ “... das Kirchenregiment ... vom weltlichen Regiment strenge zu sondern [ist]" (Stahl, 1862:13). 


\subsection{Die soewereiniteitsleer van Kuyper}

Binne die geledere van Nederlandse Calviniste moet Abraham Kuyper uitgesonder word as die persoon wat die idee van soewereiniteit in eie kring uitgebrei het om nie net vir kerkstaatverhoudings te geld nie, maar as 'n norm wat die verhouding tussen alle sosiale instellings beheer.

Abraham Kuyper is op 29 Oktober 1837 gebore. Hy behaal sy doktorsgraad in teologie aan die Universiteit van Leiden. Hy staan aanvanklik in die bediening in Breesd en Utrecht voordat hy in 1870 Amsterdam toe verhuis. Hy staan bekend as die stigter van die AntiRevolusionêre Party, wat met dié naam die Party se teenkanting teen die idees van die Franse Revolusie aandui. In 1872 word hy hoofredakteur van die Party se dagblad, De Standaard, en hy neem kort daarna ook die redakteurskap oor van 'n Christelike weekblad, De Heraut. Hy het ook 'n organisasie tot stand gebring wat hom vir Christelike onderwys op skool sou beywer. In die jare 1874 tot 1877 is hy lid van die Nederlandse parlement en vanaf 1901 tot 1905 dien hy as Eerste Minister van Nederland.

Kuyper was voorwaar 'n voortreflike en veelsydige mens: taalkundige, teoloog, akademikus, politikus, staatsman, filosoof, wetenskaplike en filantroop van formaat. Kragtens 'n nasionale proklamasie het die Nederlandse bevolking op 29 Oktober 1907 sy sewentigste verjaarsdag landswyd gevier.

Abraham Kuyper was ook stigter van die Vrije Universiteit van Amsterdam. Op 20 Oktober 1880 lewer hy die rede ter inwyding van die VU onder die opskrif: "Souvereiniteit in eigen kring".

In elke samelewing, skryf hy, is daar baie verskillende sosiale entiteite, en elke afsonderlike sosiale entiteit huisves in homself 'n oppergesag. "En dat hoogste gezag nu," sê Kuyper, "bestempelen we opzettelijk met den naam van Souvereiniteit in eigen kring, om scherp en beslist uit te drukken, dat dit hoogste gezag in elken kring niets dan God boven zicht heeft, en dat de Staat zich hier niet tusschen kan schuiven en hier niet uit eigen macht heeft te bevelen" (Kuyper, 1898:79; vgl. ook Kuyper, 1898:82; Kuyper, 1879:301). In die konteks van kerk-staatverhoudings beteken dit "van staatswege niets minder maar ook niets meer dan vrijheid voor de ontwikkeling van het geloof" (Kuyper, 1879:193). In die breër verband van maatskaplike verhoudings definieer en regverdig hy soewereiniteit in eie kring soos volg: 
God riep instellingen van allerlei orde in het leven, en aan elk van die schonk Hij een zekere mate van macht. Hij heeft alzoo de macht, die Hij uit te reiken hat, verdeelt. Hij gaf niet aan een enkele instelling al zijn macht, maar aan elk dier instellingen die macht, die met haar aard en roeping overeenkwam (Kuyper, 1879:198).

Die probleem met Kuyper se soewereiniteitsleer was dat hy skoon oorhoops geraak het met die idee en die sosiale instellings wat vir soewereiniteit in eie kring kwalifiseer, en hierdie sosiale instellings nie behoorlik onderskei het van sosiale gemeenskappe wat nie op soewereine magte aanspraak kan maak nie. Hy het alles en nog wat tot "kringe" verhef wat dan sogenaamd teenoor die staat op interne soewereine magte aanspraak kan maak (vgl. Dengerink, 1948:112113; Van der Vyver, 1972:32-34). Aldus vermeld hy op een plek die huisgesin, kerk, plaaslike bevolking (van 'n dorp of stad), die handel, industrie, wetenskap en kuns almal in een asem as 'n kring "die zijn impuls niet van den Staat ontvangt" (Kuyper, 1879:30). Elders maak hy gewag van die huisgesin, sakeonderneming, wetenskap, kuns, "en zooveel meer, maatschappelijke kringen vormen, die niet aan den Staat hun aanzijn danken, noch aan de hoogheid van den Staat hun levenswet ontleenen, maar gehoorzamen aan een hoog gezag in eigen boezem, dan evenals de Staatsouvereiniteit heerscht bij de gratie Gods" (Kuyper, 1898:79). In sy rede by die inwyding van die Vrije Universitieit noem hy in dieselfde verband die sedelike, huweliks- en maatskaplike lewe, "elk met een eigen gebied" en binne die gebied 'n eie soewerein (Kuyper, 1930:11); en dan weer van die gebied van die persoonlike, huislike, wetenskaplike, maatskaplike en kerklike lewe "die aan een eigen levenswet gehoorzamen en alle staan onder eigen overhoogheid" (Kuyper, 1930:11). Hierdie verskillende "kringe" is klaarblyklik nie van dieselfde soort nie. Die gesin en kerk is inderdaad sosiale instellings of entiteite; 'n bevolking is bloot 'n sosiale gemeenskap sonder ' $n$ organisatoriese struktuur; en die handel, industrie, wetenskap en kuns is niks meer nie as sosiaal gefundeerde modaliteite wat wel in 'n strukturele verband georganiseer kan word, maar wat op sigself nie 'n sosiale organisasie is nie. 


\subsection{Die soewereiniteitsleer van Herman Dooyeweerd}

Die leerstuk van soewereiniteit in eie kring het sy finale beslag en wetenskaplike meriete deur die Wysbegeerte van die Wetsidee van Herman Dooyeweerd (1894-1977) gekry. ${ }^{7}$

Vir die doeleindes hiervan is dit belangrik om duidelik te onderskei tussen 'n sosiale instelling/entiteit/organisasie/verband aan die een kant, en 'n gemeenskap van samehorige mense aan die ander kant (vgl. Van der Vyver, 2004b:1-5). Sosiale instellings, waaronder 'n kerkgenootskap, word organisatories saamgesnoer, kwalifiseer vir regspersoonlikheid, en is die draers van regte en verpligtinge (afgesonder van die regte en verpligtinge van hulle lede), insluitende in sommige regstelsels grondwetlike regte en verpligtinge. 'n Gemeenskap, daarenteen, bestaan uit 'n versameling persone met 'n gemeenskaplike band wat byvoorbeeld kultureel of godsdienstig gekwalifiseer mag wees, maar sonder 'n organisatoriese struktuur wat daardie groep persone as 'n bepaalde entiteit met sy eie regte en verpligtinge konstitueer. Persone met dieselfde kulturele agtergrond, geloofsbelydenis of taalgebruik kan in hierdie verband as voorbeelde uitgesonder word. As die kulturele gemeenskap 'n kulturele organisasie in die lewe roep (die F.A.K.), en as die geloofsgemeenskap 'n kerk stig (die Gereformeerde Kerk), dan is daardie organisasie of kerk 'n sosiale instelling (verband) in die bogenoemde sin. Lede van die kulturele of geloofsgemeenskap mag in ' $n$ mindere of meerdere mate in die kulturele organisasie of kerkgenootskap opgeneem word, maar bly nietemin as 'n kulturele of geloofsgemeenskap binne en buite die organisatoriese verband bestaan.

Die belangrike bydrae van Dooyeweerd kom daarop neer dat hy die verskillende soorte sosiale verskynsels prinsipieel van mekaar onderskei het en soewereiniteit in eie kring tot sosiale instellings (verbande), met uitsluiting van sosiale gemeenskappe, beperk.

\subsection{Soewereiniteit in eie kring in die praktyk}

Dit is miskien interessant om daarop te let dat godsdienstige instellings van soewereiniteit in eie kring in verskeie vorme in die grondwette van verskillende lande beskerming geniet. Singapoer

7 Vergelyk in hierdie verband in besonder Dooyeweerd (1984:169-170); Dooyeweerd (1950:51); Dooyeweerd (1962:80); Dengerink (1948:11); Spykman (1976); Van der Vyver (1972:76-78); Van der Vyver (2004b:41-48). 
beperk die interne soewereiniteit van godsdienstige groepe tot die reg om hulle eie "godsdienstige" aangeleenthede te beheer (Grondwet van die Republiek van Singapoer, art. 15(3)). lerland proklameer meer algemeen die reg van alle godsdienstige denominasies om hulle eie aangeleenthede te reël (Grondwet van lerland, art. 44.2.5). Italië verleen onafhanklikheid en soewereiniteit, "elk in sy eie kring," aan die staat en (slegs) die Rooms-Katolieke Kerk (Grondwet van die Republiek van Italië, art. 7). Peru erken soortgelyk "binne die raamwerk van onafhanklikheid en outonomie" die Rooms-Katolieke Kerk as "'n belangrike element in die historiese, kulturele en morele ontwikkeling van Peru" (Politieke Grondwet van Peru, art. 50). Paraguay verklaar in sy Grondwet dat die verhoudings tussen die staat en die Rooms-Katolieke Kerk gebaseer is op "onafhanklikheid, samewerking en outonomie," en erken ook die "onafhanklikheid en outonomie" van alle ander kerke en godsdienstige denominasies (Grondwet van Paraguay, art. 24; let daarop dat "samewerking" tussen staat en kerk alleen vir die Rooms-Katolieke Kerk beskore is en nie vir ander godsdienstige denominasies geld nie). Roemenië veroorloof die organisasie van godsdienstige instellings "in ooreenstemming met hulle eie statute", maar "onder voorwaardes wat die reg stel" (Grondwet van Roemenië, art. 29(3)). In die Tjeggiese Republiek "administreer kerke en godsdienstige verenigings hulle eie interne aangeleenthede, stel hulle eie instansies en geestelike leiers aan, en vestig godsdienstige ordes en ander kerklike instellings, onafhanklik van organe van die staat" (Handves van Fundamentele Regte en Vryhede van die Tjeggiese Republiek, art. 16(2)). Poland definieer die verhouding tussen staat en kerk en ander godsdienstige organisasies op basis van "die beginsel van respek vir hulle outonomie en die onderlinge onafhanklikheid van elkeen binne sy eie kring, asook ... die beginsel van samewerking in die individuele en algemene belang" (Grondwet van die Republiek van Poland, art. 25(3)). Oos-Timor, die wêreld se tweede jongste staat, "erken en respekteer" die verskillende godsdienstige denominasies binne die land en erken hulle vryheid "in die organisasie en in die bestaan van hulle eie bedrywighede, met toepaslike nakoming van die Grondwet en die reg" (Grondwet van die Republiek van Oos-Timor, art. 12(1); vgl. ook art. 21(1) wat beloof dat die staat "samewerking met die verskillende godsdienstige denominasies wat bydra tot die welsyn van die bevolking" sal bevorder).

Die Grondwet van die Republiek van Suid-Afrika kan in hierdie opsig uitgesonder word as een wat die beginsel van soewereiniteit in eie kring in bykans al sy verskyningsvorms handhaaf. Wat die 
soewereiniteit van godsdienstige instellings betref, verleen die Grondwet aan kerke as regspersone die regte wat in die Handves van Regte verskans is "in die mate waarin die aard van die regte en die aard van daardie regspersoon dit vereis" (art. 8(4)). Ook stel die Grondwet kerkgenootskappe as regspersone onderworpe aan grondwetlike verpligtinge wat uit die Handves van Regte voortspruit "in die mate waarin dit toepasbaar is met inagneming van die reg en die aard van enige plig deur die reg opgelê" (art. 8(2)). Volgens een grondwetkundige behels die soewereine reg van godsdienstige organisasies om hulle eie interne aangeleenthede te reguleer (die skrywer verwys na "freedom of religious autonomy") hoofsaaklik die volgende (Van der Schyff, 2003:par.87):

- die reg om hulle eie liggame en organisasies in te stel, te konstitueer en te onderhou;

- die reg om hulle eie belydenis te reguleer;

- die reg om riglyne neer te lê vir toelating van lidmate en die aanstelling van werknemers;

- die reg om godsdiensgerigte kontakte en kommunikasies in stand te hou met individue en gemeenskappe, en wel op nasionale en internasionale vlakke; en

- die reg om eiendom op te rig, te onderhou, in eiendom te hou, en om eiendom van die hand te sit.

Hoewel sosiale organisasies, en nie ook sosiale gemeenskappe nie, aanspraak het op regspersoonlikheid, word daar soms ook wel van die regte en verpligtinge van sosiale gemeenskappe gepraat, maar in dié geval vestig die regte nie in 'n omvattende verbandstruktuur wat die groep organisatories saamsnoer nie, maar bly dit regte en verpligtinge van individuele lede van die groep, wat dan - vir sover dit regte betref - uitgeoefen kan word deur die lede afsonderlik of gesamentlik met ander lede van die groep. In die volkereg word die reg op selfbeskikking aan sekere sosiale gemeenskappe toegesê.

\section{Die reg op selfbeskikking}

\subsection{Historiese perspektief}

Die reg op selfbeskikking van bevolkingsgroepe is naas die gelykheid van nasies 'n basiese norm van die volkereg. Hierdie reg word vermeld in die Handves van die Verenigde Nasies (arts. 1(2)), en beklee 'n prominente plek in die Internasionale Verdrag oor 
Ekonomiese, Sosiale en Kulturele Regte van 1966 (art. 1(1)) en die Internasionale Verdrag oor Siviele en Politieke Regte van 1966 (art. 1(1)). Bevolkingsgroepe se reg op selfbeskikking vorm ook deel van die Verenigde Nasies se Deklarasie met betrekking tot die Verlening van Onafhanklikheid aan Gekolonialiseerde Lande en Volke van 1960 en in die Deklarasie van Beginsels van die Volkereg met betrekking tot Vriendskaplike Verhoudings en Samewerking tussen State in ooreenstemming met die Handves van die Verenigde Nasies van 1970. Op streeksgebied word dieselfde beginsel onderskryf deur die Helsinki Akkoord van 1975 (Finale Akte van die Konferensie oor Sekuriteit en Samewerking in Europa, par. VIII).

Die idee van bevolkingsgroepe se selfbeskikkingsreg vind sy historiese grondslag in geskrifte van kommunistiese leiers soos Vladimir Lenin (1870-1924) en Joseph Stalin (1879-1953) (Lenin, 1914 [1947]; Stalin, 1914). Die probleem waarom dit gegaan het, was hoe om die magte van nasies te omskryf binne die konteks van die oorkoepelende ekonomiese struktuur van universele sosialisme. Stalin het 'n eerste poging aangewend om daardie nasionale bevoegdhede te omskryf, maar dit was Lenin wat dié bevoegdhede aangedui het met die frase "selfbeskikking van nasies".

Toe die Eerste Wêreldoorlog (1914-1919) einde se kant toe gestaan het, het die Amerikaanse president, Woodrow Wilson (1856-1924), insgelyks die politieke toekoms van nasies wat ingesluit was in die Ottoman-, Oostenryk-Hongaarse, Duitse en Russiese ryke betrek. In sy bekende Veertienpunttoespraak van 8 Januarie 1918 maak Wilson voorspraak vir "a free, open-minded, and absolutely impartial adjustment of all colonial claims, based upon a strict observance of the principle that in determining all such questions of sovereignty the interests of the population concerned must have equal weight with the equitable claims of government whose title is to be determined" (Wilson, 1927:Punt 5). Die frase wat deur Lenin uitgedink is en die inhoud van die Woodrow Wilson-voorstel, is mettertyd saamgevat in die volkeregtelike beginsel van die reg op selfbeskikking van bevolkingsgroepe. 
Met verloop van tyd het die reg op selfbeskikking verskillende betekenisse verkry, afhangende van die groep persone wat daarop 'n aanspraak het. 8

- In die eerste fase, wat min of meer deur die twee Wêreldoorloë afgebaken word, het die reg op selfbeskikking die volgende behels: die aanspraak op politieke onafhanklikheid van nasionale state wat tevore deel van die wêreldryke gevorm het. Dit is miskien van belang om daarop te wys dat 'n Suid-Afrikaanse verteenwoordiger by die Vredeskonferensie van Versailles, generaal J.C. Smuts (1870-1950), die mandaatstelsel ontwerp het as die aangewese metode om daardie nasionale state tot onafhanklikheid te lei.

- Na die Tweede Wêreldoorlog (1939-1945) verkry die reg op selfbeskikking 'n antikoloniale nuanse, met gekolonialiseerde volke as die bevoordeeldes en hulle politieke onafhanklikheid as die inhoud van daardie reg.

- Gedurende dieselfde fase is die reg op selfbeskikking ook toegesê aan bevolkingsgroepe wat onderworpe was aan 'n rassistiese bewind. In hierdie konteks beteken selfbeskikking nie politieke onafhanklikheid nie, maar die betrokke bevolkingsgroepe se deelname aan die politieke instellings en prosedures van die land waartoe hulle behoort. Hierdie nuanse van selfbeskikking het beslag gekry op grond van die Suid-Afrikaanse beleid van afsonderlike ontwikkeling. Suid-Afrikaanse segspersone by die Verenigde Nasies het daarop aanspraak gemaak dat die tuislandbeleid neerkom op 'n manifestasie van die reg op selfbeskikking van die swart volke van Suid-Afrika. Die internasionale gemeenskap het hierdie situasie egter anders vertolk: die swart volke was nie deel van die beleidmakers wat die beleid ontwerp het nie en het nie vir onafhanklike tuislande gevra nie. Hulle reg op selfbeskikking vereis volle deelname aan die regeringstrukture van die land.

- Met die ondergang van die wêreldryke, koloniale bewind en rassistiese politieke strukture het die klem van die reg op selfbeskikking weereens verskuif om tans te dui op die aanspraak van etniese, godsdienstige en taalgroepe binne 'n politieke

8 Vergelyk in hierdie verband Van der Vyver (2000:14-20); Van der Vyver (2004a:422-426); Van der Vyver (2004b:69-72); Van der Vyver (2005:519-20). 
gemeenskap om ongestoord die leefwyse van die groep waartoe hulle behoort, uit te leef.

\subsection{Etniese, godsdienstige en taalgroepe se reg op selfbeskikking}

Artikel 27 van die Internasionale Verdrag oor Siviele en Politieke Regte omskryf die reg op selfbeskikking wat tans van krag is soos volg:

In those states in which ethnic, religious or linguistic minorities exist, persons belonging to such minorities shall not be denied the right, in community with other members of their group, to enjoy their own culture, to profess and practise their own religion, or to use their own language.

Die Deklarasie oor die Regte van Persone Behorende tot Nasionale, Etniese, Godsdienstige of Linguistiese Minderhede van 1992 verwys op soortgelyke wyse na "die reg [van nasionale, etniese, godsdienstige of linguistiese minderhede] om, privaat of in die openbaar, vryelik en sonder inmenging van enige aard of enige vorm van diskriminasie, hulle eie kultuur te geniet, hulle eie godsdiens te bely en te beoefen, en hulle eie taal te gebruik".

Die volkeregtelike konsep van selfbeskikking plaas 'n verpligting op die draers van politieke mag om die reg op selfbeskikking van die tersaaklik dienende groepe te veroorloof. In die Deklarasie oor die Regte van Persone Behorende tot Nasionale, Etniese, Godsdienstige of Linguistiese Minderhede word die verpligting in gebiedende terme verwoord:

States shall take measures to create favourable conditions to enable persons belonging to minorities to express their characteristics and to develop their culture, language, religion, traditions and customs, except where specific practices are in violation of national law and contrary to international standards.

Die Grondwet van die Republiek van Suid-Afrika waarborg nadruklik die reg op selfbeskikking van kultuur-, godsdiens- en taalgroepe:

\section{Artikel 30}

Elkeen het die reg om die taal van eie keuse te gebruik en om aan die kulturele lewe van eie keuse deel te neem, maar niemand wat hierdie reg uitoefen, mag dit doen op 'n wyse wat met enige bepaling van die Handves van Regte onbestaanbaar is nie. 


\section{Artikel 31}

(1) Persone wat aan 'n kultuur-, godsdiens- of taalgemeenskap behoort, mag nie die reg ontsê word om, saam met ander lede van daardie gemeenskap -

(a) hul kultuur te geniet, hul godsdiens te beoefen en hul taal te gebruik nie; en

(b) kultuur-, godsdiens- en taalverenigings en ander organe van die burgerlike gemeenskap te vorm, in stand te hou en daarby aan te sluit nie.

(2) Die regte in subartikel (1) mag nie uitgeoefen word op 'n wyse wat met enige bepaling van die Handves van Regte onbestaanbaar is nie.

\subsection{Selfbeskikking en die reg op sesessie}

Bevolkingsgroepe se reg op selfbeskikking sluit nie die reg in om van bestaande staatstrukture weg te breek ten einde 'n eie staat tot stand te bring nie - selfs nie eers in gevalle waar die politieke bewindhebbers die regmatige aansprake van die betrokke etniese, godsdienstige of linguistiese minderheid verontagsaam nie. ${ }^{9}$ Hierdie verbod blyk uit die volgende oorwegings:

- Die reg op selfbeskikking is gesetel in 'n groep persone, terwyl staatstigting aan ' $n$ bepaalde territoriale gebied gekoppel is (Dooyeweerd [1984:414] definieer die funderingsfunksie van die staat as "an internal monopolistic organization of the power of the sword over a particular cultural area within territorial boundaries". Vergelyk ook Doehring, 2000:601, 602-603; Mosler, 2000:718).

- Die reg op selfbeskikking is 'n kollektiewe groepsreg (dit behoort aan individuele lede van die groep), terwyl die reg op sesessie 'n institutêre groepsreg is (dit kan alleen uitgeoefen word deur die sosiale instelling of verband waarin die groep georganiseer is, en deur middel van 'n gevolmagtigde orgaan bemiddel word).

- Bevolkingsgroepe se reg op selfbeskikking word meestal vermeld in samehang met die territoriale integriteit van bestaande state ('n beginsel wat staatsplitsing en -oorname teenstaan).

9 Vergelyk in hierdie verband Van der Vyver (2000:22-26); (2002:224-226); (2004a:427-430); (2004b:76-81); en (2005:522-528). 
Die Deklarasie oor die Regte van Persone Behorende tot Nasionale, Etniese, Godsdienstige of Linguistiese Minderhede beklemtoon daarom dat die bepalings daarvan nie op 'n wyse vertolk moet word wat die beginsels van die Verenigde Nasies met betrekking tot, onder meer, "soewereine gelykheid, territoriale integriteit en politieke onafhanklikheid van state" weerspreek nie.

Sesessie word wel in die volkereg veroorloof, maar alleen in uiters beperkte omstandighede. Regmatige sesessie vorm nie deel van die reg op selfbeskikking nie. Die Deklarasie van Beginsels van die Volkereg met betrekking tot Vriendskaplike Verhoudings en Samewerking tussen State in ooreenstemming met die Handves van die Verenigde Nasies erken die herstrukturering van staatsgrense indien die sesessiebesluit "vryelik deur die bevolking" geneem word - en dit beteken die deursnee van die bevolking in sy geheel en nie net van die inwoners van die gebied wat wil afstig nie. Die volkereg veroorloof ook die verandering van landsgrense in terme van 'n vredesverdrag wat gewapende geweld tot 'n einde bring. Die verdeling van die vroeëre Joegoslavië in die Tjeggiese Republiek en Slovakië is 'n voorbeeld van die eerste geval, terwyl die sesessie van Eritrië as voorbeeld van die laasgenoemde norm geld.

\section{Kuyper en die reg op selfbeskikking}

Bevolkingsgroepe se reg op selfbeskikking stem ooreen met Kuyper se beskouing van soewereiniteit in eie kring en nie soseer met dié van Dooyeweerd nie. Die groepe wat aanspraak kan maak op die reg op selfbeskikking is naamlik almal sosiale gemeenskappe en nie sosiale entiteite, of in Dooyeweerd se terminologie "verbande" nie. Terwyl alleen sosiale entiteite volgens Dooyeweerd met soewereiniteit in eie kring toegerus is, het Kuyper 'n verskeidenheid sosiale gemeenskappe by sy siening van soewereiniteit in eie kring inbegryp. Daarmee het hy in wese erkenning verleen aan die reg op selfbeskikking van (nie-institutêre) gemeenskappe.

Dit sou natuurlik voorbarig wees om te wil sê dat Kuyper verantwoordelik was vir, of selfs net 'n invloed gehad het op, die hedendaagse volkeregtelike verordening van etniese, godsdienstige en linguistiese gemeenskappe se reg op selfbeskikking. Dit staan egter soos 'n paal bo water dat hy insigte geïnisieer en voortgeplant het wat met verloop van tyd - kennelik deur die toedoen van ander invloede - in 'n groeiende wêreldmoraal opgeneem is. Juis daarin vestig die krag van die Calvinisme, naamlik dat dit geskoei gebly het op 'n waardesisteem wat universeel geldig is en op sterkte van die 
inherente etiese behore daarvan ook kon posvat, in die algemene denkpatroon van 'n gesekulariseerde stategemeenskap.

Theo van der Merwe was altyd vir my die toonbeeld van daardie relatief klein kring van gelowiges wat, op 'n heel beskeie manier, met beginselvaste denke en 'n voortreflik voorbeeldige lewenspatroon die invloed van 'n Skrifmatige etiek ver buite die kring van sy eie geloofsgenote kon uitdra.

\section{Geraadpleegde bronne}

ALTHUSIUS, J. 1961 [1614]. Politica methodicè digesta atque exemplis et profanis illustrata. Herborn (Uitg. Friedrich, C.J.). Cambridge: Harvard University Press.

BESELER, G. 1885. System des gemeinen deutschen Privatrechts. (4e vermehrte und verbesserte Auflage.) Berlin: Weidmannsche Buchhandlung.

CALVYN, J. 1913 [1568]. Institutio christianae religionis. (Translated by Allen, J.) Philadelphia: Presbyterian Board of Christian Education.

CALVYN, J. 1949. Tracts and treaties on the doctrine and worship of the church. (Translated by Beveridge, H.) Grand Rapids: Eerdmans.

CALVYN, J. 1964 [1553]. Brief aan Antistes Sulzer. (In Baum, G., Cunitz, E. \& Reuss, E., eds. XIV loannis Calvini opera quae supersunt omnia, 1793. Brunsvigae: Schwetschke, 1863-1900/New York: Johnson Reprint Corp. p. 614-616.)

DENGERINK, J.D. 1948. Critisch-historisch onderzoek naar de sociologische ontwikkeling van het beginsel der "souvereiniteit in eigen kring" in de $19 \mathrm{e}$ en 20 e eeuw. Kampen: Kok.

DOEHRING, K. 2000. State. (In Bernardt, R., ed. Encyclopedia of public international law. IV. Amsterdam: Elsevier. p. 600-605.)

DOOYEWEERD, H. 1950. De strijd om het souvereiniteitsbegrip in de moderne rechts- en staatsleer. Amsterdam: Paris.

DOOYEWEERD, H. 1962. Verkenningen in de wijsbegeerte, de sociologie en de rechtsgeschiedenis. Amsterdam: Buijten \& Schipperheijn.

DOOYEWEERD, H. 1984. A new critique of theoretical thought. III. (Translated by Freeman, D.H. \& De Jongste, H.) Ontario: Paideia.

GROEN VAN PRINSTERER, G. 1846/1847. Ongeloof en revolutie. (Bewerkt door Smitskamp, H.) Franeker: Wever.

GROEN VAN PRINSTERER, G. 1849. Het recht der hervormde gezindheid. Amsterdam: Müller.

GROEN VAN PRINSTERER, G. 1855. Narede van vijfjarige strijd. Utrecht: Kemink.

GROEN VAN PRINSTERER, G. 1858. Proeve over de middelen waardoor de waarheid wordt gekend en gestaafd. Amsterdam: Höveker.

GROEN VAN PRINSTERER, G. 1862. Ter nagedachtenis van Stahl. Amsterdam: Höveker.

GROEN VAN PRINSTERER, G. 1872. Handboek der geschiedenis van het vaderland. Leiden: Luchtmans.

KUYPER, A. 1879. Ons program. (Met bijlagen.) Amsterdam: Kruyt. 
KUYPER, A. 1898. Het Calvinisme: zes Stone-lezingen in October 1898 te Princeton, N.J. gehouden. Kampen: Kok.

KUYPER, A. 1930. Souvereiniteit in eigen kring: rede ter inwijding van de Vrije Universiteit. (3e druk.) Kampen: Kok.

LENIN, V.I. 1914. The right of nations to self-determination. (In The essentials of Lenin in two books. I. London: Lawrence \& Wishard. p. 564-611, 1947.)

MOSLER, L. 2000. Subjects of international law. (In Bernardt, R., ed. Encyclopedia of public international law. IV Amsterdam: Elsevier. p. 710727.)

PUCHTA, G.F. 1865. Cursus der Institutionen, (6e neu vermehrte Aufl. besorgt von Rudorff, A.E.) Leipzig: Breitkopf \& Härtel.

SPYKMAN, G. 1976. Sphere sovereignty in Calvin and Calvinist tradition. (In Holwerda, D.E., ed. Exploring the heritage of John Calvin. Grand Rapids: Baker Book House. p. 163-208.)

STAHL, F.J. 1853. Der Protestantismus als politisches Prinzip. Berlin: Schultze.

STAHL, F.J. 1862. Die Kirchenverfassung nach Lehre und Recht der Protestanten. (2. Aufl.) Erlangen: Bläsing.

STALIN, J.V. 1914. Marxism and the national question. (In Joseph V. Stalin selected works. California: Cardinal Publishers. p. 47-93, 1971.)

VAN DER SCHYFF, G. 2003. Freedom of religious autonomy as an element of the right to freedom of religion. Tydskrif vir die Suid-Afrikaanse Reg: 512539.

VAN DER VYVER, J.D. 1972. Die juridiese funksie van staat en kerk: 'n kritiese analise van die beginsel van soewereiniteit in eie kring. Durban: Butterworths.

VAN DER VYVER, J.D. 1991. Sovereignty and human rights in constitutional and international law. Emory International Law Review, 5:321-443.

VAN DER VYVER, J.D. 1996. Legal dimensions of religious human rights: constitutional texts. (In Van der Vyver, J.D. \& Witte, J., eds. Religious human rights in global perspective: legal perspectives. The Hague: Nijhoff. p. xi-xlvii.)

VAN DER VYVER, J.D. 2000. Self-determination of the peoples of Quebec under international law. Journal of Transnational Law and Policy: 1-37.

VAN DER VYVER, J.D. 2001. Sphere sovereignty of religious institutions: a contemporary Calvinistic theory of church-state relations. (In Robbers, G., ed. Church autonomy. Frankfurt a.M.: Peter Lang. p. 645-681.)

VAN DER VYVER, J.D. 2002. The jurisprudential legacy of Abraham Kuyper and Leo XIII. Markets and Morality, 5(1):211-249.

VAN DER VYVER, J.D. 2004a. The right to self-determination and its enforcement. ILSA Journal of International and Comparative Law, 10(2):421-436.

VAN DER VYVER, J.D. 2004b. Leuven lectures on religious institutions, religious communities and rights. Leuven: Peeters.

VAN DER VYVER, J.D. 2005. Limitations of freedom of religion or belief: international law perspectives. Emory International Law Review, 19(2):499-537.

WILSON, W. 1927. Fourteen points address delivered on January 8, 1918 to a joint session of Congress by President Woodrow Wilson. (In Baker, R.S. \& Dodd, W.E., eds. Public Papers of Woodrow Wilson: War and Peace. New York: Harper. p. 155-159.) 


\section{Wetgewing}

Grondwet van die Republiek van Italië (1948).

Grondwet van die Republiek van Oos-Timor (2002).

Grondwet van die Republiek van Poland (1997).

Grondwet van die Republiek van Singapoer (1963).

Grondwet van die Republiek van Suid-Afrika (1996).

Grondwet van lerland (1937).

Grondwet van Paraguay (1992).

Grondwet van Roemenië (1991).

Handves van Fundamentele Regte en Vryhede van die Tjeggiese Republiek (1992).

Politieke Grondwet van Peru (1993).

\section{Volkeregtelike traktate}

Charter of the United Nations, 1946/47. Yearbook of the United Nations. p. 831843.

Declaration on principles of international law concerning friendly relations and co-operation among states in accordance with the Charter of the United Nations, G.A. Res. 2625 of 24 Oct. 1970, 25 GAOR Supp. (No. 28) p. 121124, U.N. Doc. A/8028 (1970).

Declaration on the granting of independence to colonial countries and peoples, G.A. Res. 1514 of 14 Dec. 1960, 15 GAOR Supp. (No. 16) p. 66-67, U.N. Doc. A/4684 (1960).

Declaration on the rights of persons belonging to national or ethnic, religious and linguistic minorities, G.A. Res. 47/136 of 18 Dec. 1992, 47 U.N. GAOR Supp. (No. 49), p. 210-212, U.N. Doc. A/RES/47/135 (1992).

Final act of the conference on security and co-operation in Europe. International Legal Materials, 14:1292-1325 (1975).

International covenant on civil and political rights. G.A. Res. 2200 (XXI) of 16 Dec. 1966, 21 U.N. GAOR Supp. (No. 16) p. 52-58, U.N. Doc. A/6316.

International covenant on economic, social and cultural rights. G.A. Res. 2200A (XXI) of 16 Dec. 1966, 21 U.N. GAOR Supp. (No. 16) p. 49-52, U.N. Doc. A/6316.

\section{Kernbegrippe:}

kerk-staatverhoudings

reg en godsdiens

reg op selfbeskikking van etniese, godsdienstige en

taalgemeenskappe

reg op sesessie

soewereiniteit in eie kring

sosiale instellings en sosiale gemeenskappe 


\section{Key concepts:}

church-state relations

law and religion

right to self-determination of ethnic, religious and linguistic communities

right to secession

social institutions and social communities

sphere sovereignty 